\title{
Harmony of practice
}

The European Science Foundation's general assembly heard of progress last week in controlling genetic manipulation experiments. Chris Sherwell reports from Strasbourg

EUROPEAN initiatives in controlling recombinant DNA research will continue in spite of the hiatus reached in the United States, where no legislation now seems likely in the coming year. The pace set by the USA hitherto has slowed considerably in recent weeks with evidence that the dangers are less than at first expected, and the bill introduced by Senator Kennedy has now been withdrawn.

European efforts, however, though largely focused on the subject of legislation, are not directed at producing harmonisation of individual countries' guidelines. The chances of doing this are now widely regarded as negligible, more because of the work each country has put into creating guidelines suited to its own circumstances than because scientists have differed in their estimates of what are conjectural risks. Moreover, in practice the decisions of the European countries' equivalent to GMAG (Britain's Genetic Manipulation Advisory Group) have proved to be very similar across a broad range of experiments.

The aim now is therefore directed at harmonisation of practice in the individual countries. The intention is that individual representatives of national genetic manipulation advisory groups should supply lists of sanctioned experiments together with the relevant containment conditions. Anomalies would be discussed, and countries out of line would be expected at least to reconsider their position. Harmonisation would thus consist in concurring at regular meetings on decisions already taken.

The meetings, which should now take place every six months, are of the liaison committee for recombinant DNA research of the European Science Foundation (ESF). This met for the first time on 15 March this year, and again on 19-20 September. As a result of the first meeting, at which various countries' practices were surveyed, a small group of legal experts and scientific advisers met on 22 June to discuss common elements for possible controlling legislation. It considered licensing of facilities, consultation and compliance with controlling bodies, and an issue which had tormented the liaison committee meeting,

\section{that of patents.}

According to the ESF annual report agreed in Strasbourg last week, the September meeting supported the legal committee's finding that researchers' interests would be best protected if national committees requested information necessary only to assess suitable safety precautions. That the subject of legal safeguards and patents is a potential problem is revealed by the British case. Here, GMAG's dual role as both a technical advisory committee and as a watchdog for the public interest has made winning the confidence of industrialists, for whom the patents question is highly relevant, especially difficult.

Elsewhere the conflict of interest implicit in this dual role is resolved by creating a small technical advisory committee which looks at individual cases in detail and then delivers suitably edited reports to the full committee. It is a solution adopted on the European level as well: the ESF liaison committee's technical advice comes from EMBO's standing advisory committee on recombinant DNA research, which consists solely of molecular biologists.

The September liaison committee meeting also agreed on certain general points-that any effective legislation should provide for notification to some responsible body, and for licensing and inspection of facilities by that body. The idea that individual projects should receive prior approval was not unanimously endorsed, but the keeping of records and the idea of legislative review did receive support.

The liaison committee also considered technical safety issues which were the basis of a questionnaire distributed on the subject following a separate and informal meeting in June. The assistance of the EMBO committee will be sought on discrepancies between decisions of national safety committees and the revised NIH guidelines. Other areas of interest include the lowering of safety measures where the DNA to be cloned is pure, the criteria of pathogenicity for purified recombinant DNA molecules, the principles and application of biological containment, and the safety measures nceded for recombinant DNA research using plant and animal viruses.

Out of all this a pan-European code may or may not emerge. For the moment, the objective is practical. And it has the useful purpose of serving the mutual interests of recombinant DNA researchers and of the European Science Foundation.

\section{Europe's danger}

A WARNING about the future of science in Europe is contained in the annual report of the European Science Foundation (ESF), endorsed last week in Strasbourg at its third general assembly. But while the threat has not been spelled out quite so cogently before by an international scientfic body, the ESF announced no comprehensive plan to help counter the danger.

The problem, a product of the mid1970 s, was summed up by Sir Brian Flowers, re-elected to the ESF presidency for another three years. If the trend of dwindling support for the important innovative research done by Europe's small scientific groups continued for too long, he told a press conference, the progress of science would be affected at the point of origin. But he confessed: "This subject was not discussed very much". He added only that it was "accepted by everybody present".

Sir Brian went on to list the assembly's achievements. Apart from moves in the field of recombinant DNA (see accompanying story), these included the establishment of a committee to conduct a feasibility study on a synchroton radiation facility, progress of an ad hoc group on taxonomy in the fields of zoology and botany, and an elevation in the status of ESF committees on the social sciences and the humanities.

Some concern was voiced privately last week at the number of ESF committees: delegates saw a need for more tangible action. At present there is only the European Training Programme for Brain and Behaviour Research, which awards grants for travel and training, and financial support for the mathematics and physics research programme of the Institut des Hautes Etudes Scientifiques. Nor did the ESF make any statement of its position on the issue of human rights.

The ad hoc group to study the design, costs and site of a European synchrotron radiation facility will be headed by Professor Hagedoorn of the Netherlands. Its predecessor, under Professor Maier-Leibnitz, found that research using such radiation sources, which is parasitic on high energy physics facilities, had reached a stage where the lack of control undermined progress. The hope is that work will start on a European facility in 1980 , to be ready by 1985 . This will be in addition to such other European projects as CERN, ILL, EMBL, EISCAT, JET and the European observatories.

The decisions concerning the social sciences and the humanities add two standing committees (the former to be chaired by Jean-Jaques Salomon) to the two in existence, which embrace the science research councils (ESRC) and the medical research councils (EMRC). But the idea of helping post-doctoral students in these two areas through fellowships and workshops-which in expanded and broadened form would obviously help counter the danger to science described in the ESF report met an obstacle over how any such scheme would be financed. It proved to be the only spark of controversy at an otherwise routine gathering.

Chris Sherwell 